\title{
Among the Pilgrims, but Not of Them - Individualist Intellectuals on Their Pilgrimage to Mecca
}

\begin{abstract}
How does an individualist and skeptical intellectual who is not religious in the usual sense experience the pilgrimage to Mecca in modern times, when he or she is only one among a huge mass of pilgrims? In order to offer an answer to this question, this contribution will look at two literary texts which are quite different in terms of author, time, and genre, but show a number of similarities in terms of observations, impressions, reflections, and feelings. The first is Lost in the Crowd, the travel diary published by the Iranian thinker Jalal Al-e Ahmad (19231969) in 1966 on his Hajj experiences in 1964; the second is the novel Fitna by the Emirati author Amira al-Qahtani, which appeared in 2007 and takes the pilgrimage as a frame-story. It will be argued that Al-e Ahmad established a discursive tradition that had an impact on religious doubters in Iran and beyond.
\end{abstract}

Keywords: Pilgrimage to Mecca (Hajj), Jalal Al-e Ahmad, Lost in the Crowd, Amira al-Qahtani, Fitna, religious skepticism, socio-political criticism

\section{Introduction}

Given the huge number of Muslims who perform the Hajj or 'Umra every year, one may assume that an individualist, skeptical intellectual who is not religious in the usual sense may not feel very comfortable among the mass of pilgrims. As the pilgrimage to Mecca is one of the five pillars of Islam, and thus all Muslims are obliged to undertake it at least once in their lives, as long as they are financially and physically able to do so, one may speculate that every Muslim/a approaching the end of life has the wish to make this journey. But, what about those persons who are actually in their prime? What is it that motivates them to undertake the journey to the sacred sites? In general, there are limited studies into motivations for pilgrimage. This is not only, Ruth Blackwell remarks, because it is a difficult 
topic to research, as motivation for pilgrimage is multi-faceted and multi-layered, influenced by individual belief, social and cultural context, moreover changing over time and altered expectations; another difficulty is that when asked, many pilgrims may not be able to articulate their motives, nor may they wish to admit that they need to accumulate merit or remove sin - the traditional reasons for pilgrimage. ${ }^{1}$ However, motives for visiting sacred sites, have been found to affect behavior, most likely by conforming to overt and covert norms.

To the best of my knowledge, the only empirical studies on the motivation of non-believers ${ }^{2}$ to go on pilgrimage have been conducted with regard to pilgrims on their way to Santiago de Compostela. ${ }^{3}$ This medieval Christian pilgrimage route (the Camino) has been revived and recreated over the past three decades, partly due to best-selling books such as The Pilgrimage (1987/1998) by the Brazilian lyricist and novelist Paulo Coelho (b. 1947). ${ }^{4}$ In contrast to the Camino, the Hajj is restricted to (formal, nominal) Muslims, its ceremonies are more or less prescribed, and the motivations mentioned in the conventional travel accounts are rather standardized. In order to shed light on the motives of religious doubters to go on Hajj and on the effects of this experience on them, I will look at two literary texts which are quite different in terms of author, time, and genre, but show a number of similarities in terms of observations, impressions, reflections, and feelings. The first is Lost in the Crowd, the travel diary published by the Iranian thinker Jalal Al-e Ahmad in 1966 on his Hajj experiences in 1964; the second is the novel Fitna by the Emirati author Amira al-Qahtani, which appeared in 2007 and takes the pilgrimage as a frame-story. ${ }^{5}$

1 R. Blackwell, Motivation for Pilgrimage: Using Theory to Explore Motivations, "Scripta Instituti Donneriani Aboensis" 2010, vol. 10, pp. 26-27, 33, 35.

2 For a brief overview of the diversity of non-believers, see T.J., Coleman [III] , R.W. Hood [Jr.], H. Streib, An Introduction to Atheism, Agnosticism, and Non-Religious Worldviews, "Psychology of Religion and Spirituality" 2018, vol. 10, no. 3, pp. 203-206, an introduction to the special issue of the journal on the topic.

M. Farias et al., Atheists on the Santiago Way: Examining Motivations to go on Pilgrimage, "Sociology of Religion: Quarterly Review" 2019, vol. 80, esp. pp. 38-40; T. Schnell, S. Pali, Pilgrimage Today: The Meaning-Making Potential of Ritual, "Mental Health, Religion and Culture" 2013, vol. 16, no. 9, esp. pp. 895-901. On the popularity of the Camino see also J. Jeffrey, The Making of a Modern Pilgrim: The Camino de Santiago, "The Humanist" 2018, Jan.-Feb., pp. 25-29.

4 Amira al-Qahtani mentioned Coelho as one of her favorite authors in an interview with "Elaph" in 2008 (cf. R. Badry, Trapped in Between Two Worlds: The Novel "Fitna" (2007) by Amira AlQahtani [in:] Proceedings of the $3^{\text {rd }}$ International Conference on the History of Arabic Literature, ed. O. Khomitska, Kiev 2020, p. 23). For Coelho's Pilgrimage see, e.g., S. Kotiah, A la Brasileña: Pilgrimage in Paulo Coelho's Writings, "Asian Journal of Latin American Studies" 2016, vol. 29, no. 2, esp. pp. 37-48.

5 J. Āl-e Ahmad, Lost in the Crowd, transl. J. Green, Washington, D.C. 1985, pp. 5-124; J. Ā1-e Aḥmad, Khasī dar mīqāt: Safar-nāme, Tehran 1375/1996; A. Al-Qahtani, Fitna: Roman, transl. C. Battermann, Cologne 2011; A. Al-Qaḥtānī, Fitna, Beirut 2007. When Lost in the Crowd is quoted, or summarized in the text or notes, the first page number refers to the English translation and the second number to the Persian original in its fourth edition. Similarly, in the case of Fitna, the first number refers to the German translation and the second to the Arabic original in its second edition. 


\section{Biographical Sketch of the Authors and Synopsis of the Respective Texts}

The prominent Iranian writer and social critic Jalal Al-e Ahmad ${ }^{6}$ (1923-1969) was born into a religious family; his father, his older brother, two brothers-in-law and a nephew were all Twelver Shiite clerics. ${ }^{7}$ Contrary to his father's wishes, Al-e Ahmad decided to become a teacher. Though he did quit direct political activity after the US-led coup d'état against Mosaddeq in 1953, Marxism, and other leftist analyses of modernity, had a lasting effect on his writings, the most popular of which is Gharbzadegi (lit. "Western-struck-ness", 1962), a harsh critique of incomplete modernization and unreflecting Westernization. His travel diary with the unusual title Khasi dar miqat (lit. "A Chip of Wood/Piece of Straw on the Way to the Holy Shrine") $)^{8}$ is a far more literary text than Gharbzadegi. To some extent (cf. ethnographic descriptions, information on the rituals), the travelogue follows the traditional Persian genre of Safarnameh, for nearly a thousand years closely connected with the name Naser-e Khosrow (1004-1077 or 1088), the Persian poet, traveler, philosopher, and Ismaili propagandist, whom Al-e Ahmad mentions several times in Lost in the Crowd. ${ }^{9}$ However, as Michael C. Hillmann puts it, Al-e

6 Throughout the text, I will use a simplified transliteration. The only exceptions are the bibliography and quotes from other sources.

7 For the biography and work of Al-e Ahmad see, for instance: H. Dabashi, Theology of Discontent: The Ideological Foundations of the Islamic Revolution in Iran, New York 1993, pp. 39-101; M.C. Hillmann, Introduction: Cultural Dilemmas of an Iranian Intellectual [in:] J. Āl-e Ahmad, Lost in the Crowd, transl. J. Green, Washington, D.C. 1985, pp. vii-xxxiii; C.V. Pedersen Āl-i Ahmad, Jaläl [in:] Encyclopaedia of Islam, THREE, eds. K. Fleet et al., https://referenceworks.brillonline. com/entries/encyclopaedia-of-islam-3/al-i-ahmad-jalal-COM_24840?s.num=0\&s.rows=100\&s.f.s2 parent=s.f.book.encyclopaedia-of-islam-3\&s.q=Al-i+Ahmad (access: 21.02.2020); J.W. Clinton, Äl-e Ahmad, Jalāl [in:] Encyclopaedia Iranica, ed. E. Yarshater, http://www.iranicaonline.org/articles/ale-ahmad-jalal-1302-48-s (access: 21.02.2020). For an analysis of Lost in the Crowd, arguing against his alleged return to faith, see A.S. Chaudhary, Religions of Doubt: Religion, Critique, and Modernity in Jalal Al-e Ahmad and Walter Benjamin, PhD-thesis, Columbia University 2013, esp. pp. 250-298, and S. Shiravand, Sovereignty without Nationalism, Islam without God: A Critical Study of the Works of Jalal Al-e Ahmad, PhD-thesis, Dept. of Sociology, University of Alberta 2015, esp. pp. 233-286. Cf. also the review by F. Jahanpour, (Review) "Lost in the Crowd". By Jalal Al-e Ahmad. Translated by John Green with Ahmad Alizadeh and Farzin Yazdanfar. Washington, D.C.: Three Continents Press, 1985, "Iranian Studies" 1985, vol. 18, no. 2/4, pp. 449-485. For a short assessment of Al-e Ahmad's significance, see M. Axworthy, The Revolution that Shook the World, "New Statesman" 2019, 15 February, vol. 148, issue 5458, p. 28.

8 G. Nikpour (Revolutionary Journeys, Revolutionary Practice: The Hajj Writings of Jalal Ale Ahmad and Malcom X, "Comparative Studies of South Asia, Africa and the Middle East" 2014, vol. 34, no. 1, p. 72) translates the title as follows: "A Speck of Dirt in the Holy Shrines", but usually Green's translation is given. Miqat can be translated as "meeting points", "entrances" and refers to the places where the pilgrims put on the ihram, the pilgrim's garb (cf. J. Āl-e Ahmad, Lost in the Crowd, p. 58, note 98; and J. Green, Translator's Glossary and Bibliography [in:] J. Āl-e Ahmad, Lost in the Crowd..., pp. 129-130).

9 On Naser-e Khosrow's travelogue and his pilgrimages to Mecca cf., e.g., A. Nanji, Nāṣir-i Khusraw [in:] The Encyclopaedia of Islam, second edition, ed. P. Bearman, https://referenceworks.brillonline.com/entries/encyclopaedia-of-islam-2/nasir-i-khusraw-SIM_5827?s.num=215\&s.rows=100\&s. start=160 (access: 21.02.2020); A.C. Hunsberger, Nasir Khusraw, the Ruby of Badakhshan: A Portrait of the Persian Poet, Traveller and Philosopher, London-New York 2000, pp. 11-12, 174-197. During 
Ahmad's travel account "is almost unprecedented in Persian literature in terms of self-revelation of personal and cultural doubts, misgivings, and dilemmas". ${ }^{10}$

Unlike Al-e Ahmad, not much is known about Amira al-Qahtani, who seems to be unwilling to reveal details on her life. Not even a photo of her is available. But as she confirmed by tweet and email, she is an Emirati, from Dubai to be precise, and the daughter of Emirati parents. ${ }^{11}$ She studied business management and currently works in the public sector. Apart from her novel, Amira al-Qahtani has published articles and comments on contemporary cultural and social trends in the Saudi Al-Jazirah newspaper as from 2007. ${ }^{12}$ Her debut novel Fitna appeared in 2007 in two editions with two different covers. The second edition I am using shows a stylized version of the "circling" of the Ka 'ba. The picture was designed by the Saudi artist Ahmed Mater and symbolizes "the magnetic effect" of the Ka 'ba. ${ }^{13}$ The Arabic word Fitna, literally "trial, test, temptation", is an extremely negative metaphor in Arab-Islamic discourse with the predominant political connotation of turmoil and civil unrest, and a gender-specific meaning of chaos provoked by women's attractiveness and sexuality. Fitna is not only the title of the novel but also the (symbolic) name of the heroine, the daughter of a Qatari mother and a Saudi father. ${ }^{14}$ It is a first-person narrative although the lines between the author and the heroine are blurred. The focus of the narrative is on the emotional and mental life of the main character, but the brief passages describing her impressions on the Hajj show similarities with Al-e Ahmad's doubts and critique. As with Al-e Ahmad's travelogue, al-Qahtani's novel is full of both ambiguities and contradictions on the one hand, and subtle, biting humor, irony, self-mockery, and situational comedy on the other. Another common feature of the two texts is the constant rapid switches between description of the scenery, critical sociopolitical remarks, poetic or even philosophical passages, and discussion of the narrator's own sensitivities..$^{15}$ This may be interpreted as a manifestation of the hurry during the journey, but also as a reflection of the protagonists' changing mood. ${ }^{16}$

the Hajj Al-e Ahmad also reads another Hajj travelogue by a Qajar prince and governor (i.e. Farhad Mirza, 1818-1888; on him, who performed the pilgrimage in 1875, and his travelogue published two years later, see K. Eslami, Farhād Mìrzā Mo tamad-Al-Dawla [in:] Encyclopaedia Iranica, ed. E. Yarshater, http://www.iranicaonline.org/articles/farhad-mirza-motamad-al-dawla), whom he depicts at the end as ignorant (106/56). - It is noteworthy that Al-e Ahmad specifically recalls the heterodox legacy in Islam, in addition to Naser-e Khosrow citing the Sufi Bistami (cf. below).

10 M. C. Hillmann, op. cit, p. xxxi.

11 See R. Badry, op. cit., p. 11.

12 Ibid., pp. 11-12, and note 8 (p. 12). In her interview with "Elaph", Amira al-Qahtani announced that her next book would be a fantasy novel. But this project seems not to be realized yet. However, in Fitna she already explores the line between fantasy and reality.

13 Ibid., pp. 12-13, and note 11 (p. 13).

14 Ibid., pp. 13-14. Thus, in what follows, Fitna (in italics) refers to the title of the novel, and 'Fitna' (in single quotation marks) refers to its heroine.

15 J. Al-e Ahmad frequently scolds himself for self-preoccupation (p. 13/20, 21/32, 45/66) or coming back to the analyses offered in Gharbzadegi (p. 29/63, 73/110) which he calls "nonsense" at least twice in Lost in the Crowd (p. 18/28, 55/81).

16 Both protagonists also refer to aspects of unequal treatment of pilgrims: Al-e Ahmad mentions that the Iranian pilgrims had to come by airplane, whereas the Turkish pilgrims were allowed to come by 


\section{The Protagonists' Self-portrayal and their Motives for Performing the Haij}

From the very beginning the protagonists of the two texts present themselves as reluctant or at least unlikely pilgrims. Both seem to perceive going on Hajj not as a religious duty, but more as a private obligation to accompany their close relatives, specifically to take care of older family members: in the case of Al-e Ahmad his uncle (aged 80) ${ }^{17}$, in 'Fitna's' case her mother. The Iranian author initially confesses that he gave up praying more than 20 years ago, and when resuming it in the pilgrim's assembly area in Tehran before flying to Jeddah, he feels "like a hypocrite. [...] If it isn't hypocrisy, neither is it faith. You just do it to blend in with the crowd. But does one go to Mecca without praying?" (p. 6/10) Time and again he questions his own motives for going on pilgrimage and provides different options (e.g. p. 58-59/80). When asked by other pilgrims, why he came, he has no answer (p. 68/100).

In one passage, referring to Bistami ${ }^{18}$, the ninth century Iranian Sufi, he calls himself "the other atheist/heretic" (zandiq-e digar). On his return flight to Iran, he notes, "I've come on this trip mostly out of curiosity [...], to look without expectations. [...] Anyway, it was necessary to see, to be there, to go, and to witness, to see what changes there have or have not been since the time of Nāșir-i Khusraw" (p. 123-124/181, 183). To seek for traces of his older brother who died in Medina 13 years ago under mysterious circumstances (cf. p. 27/40, 28/41; 115/169), he mentions as the main reason for his journey (p. 124/183). For her part, 'Fitna' wonders before her flight to Medina, "Can't we atone for our transgressions by doing other good things?" (p. 9/7) A few lines later she admits that she is not going to Mecca to leave her sins there, adding “I don't deny them, but I don't want to get rid of them [...] so that they remind me that I am a human being" (p. 11/9-10). In Mina, she is confronted for the first time with a great mass of pilgrims, as she, her mother and older brother had arrived in Mecca late, after the other pilgrims had already set off for Mina. There, she asks herself, apparently shying away from an answer, "Every Muslim wants to do the pilgrimage to Mecca, except me. Hence, [...] Am I not a Muslima?" (p. 55/52-53) More than once, she describes her performance as a masquerade and as "chameleon-like" (p. 35/33-34; 59/57; 92/90) because she is torn between conformity and rebellion, between outward, mainly self-confident behavior and inner agitation and fears. ${ }^{19}$

bus (p. 25/37). When 'Fitna' heard that the road to Mina was blocked because of an official delegation, she asks why the diplomats could not even here forget about their diplomatic passports (p. 115/111).

17 "The age of Noah" in Al-e Ahmad's words (p. 76/111). On several occasions, Al-e Ahmad describes how he is assisting other helpless pilgrims, mainly in his group but also beyond. Relating to his own group he reports: "I have now gradually become a full-time doctor and secretary for our group..." (p. 70/103). But also in post offices he is asked by people for help (p. 110/162).

18 On Abū Yazīd al-Bisțāmī (as an example for 'intoxicated' or 'extreme' mysticism) see, e.g., A. Knysh, Islamic Mysticism: A Short History, Leiden 2010, pp. 69-71 and passim.

19 Since the first moment of the journey, 'Fitna' is in a constant worry that her mother, who is the main person in her life after her divorce and her father's death, may not survive the Hajj. When she suddenly cannot find her mother on the plain of Arafat, i.e. at the climax of the Hajj (cf. D.E. Long, 


\section{The Protagonists' Observations, Impressions, and Feelings during the Haij}

Throughout the texts, both protagonists give the impression that they are among the hajjis-to-be, but not really part of them, remaining much more detached observers than whole-heartedly committed participants during the pilgrimage. Though they try to complete the mandatory program of the Hajj and to comply with the external forms of the rituals and norms, they sometimes fail ${ }^{20}$, and cannot resist commenting on what disturbs them or what they perceive as unacceptable and unreasonable.

For Al-e Ahmad, writing his diary, and not worshiping, is his primary concern during the pilgrimage. Documenting everything, he sees and feels enables him to isolate himself. He often walks around on his own to explore the environment and to talk to other pilgrims and residents, thereby getting information on their religious, social and political attitudes (cf. Naser-e Khosrow). On his flight back home, he again takes refuge in the notebook because of lack of space for him and a few other persons who boarded late, and remarks: "What would have happened on the trip if I hadn't had the companionship of this notebook?" (p. 122/180)

'Fitna's' chances to isolate herself are limited, she escapes to her memories; often she talks to herself without noticing it. There are only two interactions with other pilgrims which are described in greater detail, and end up with a mutual lack of understanding (pp. 101-104/97-100; 170-180/162-171).

Many of the tensions and ambiguities of the protagonists seem to be already indicated by the books' titles. Khasi dar miqat reflects Al-e Ahmad's fear of dissolution into an unfamiliar, anonymous mass of pilgrims - an interpretation he himself suggests in the following passage (shortly after arriving in Mecca): "I saw that I was just a 'piece of straw' [khasi] that had come to the 'Miqāt', not a 'person' [kasi] coming to a 'rendezvous'. I saw that 'time' is an 'infinity', an ocean of time, and that 'Miqāt' exists always and everywhere, and with the self alone" (p. 57-58/84-85). Yet, a few pages earlier, he had convinced himself, that "It's easy to be among the people and not be a part of them" (p. 42/67). 'Fitna' also alludes to the tension between individual and society, but from a gender perspective, as her focus is on the discrimination against women in Arab/Gulf society, which generates psychological problems on the one hand and may lead to chaos and rebellion on the other. She perceives the family and social control over her

The Hajj Today: A Survey of the Contemporary Makkah Pilgrimage, Washington, D.C. 1979, p. 19), she starts to react hysterically and has to take tranquillizers (pp. 60-62/58-60).

20 In addition to the following remarks, see, for instance Al-e Ahmad, p. 83/121: Once, while reading the Quran, he was making notes on his personal problems at the margins of the Holy Scripture. He stopped it when he saw that his companions "couldn't stand to see it". Another time he is tempted to pick up a wrist watch which is laying on the ground but is not his. When he recalls that this is incorrect behavior, especially on the Hajj, he puts it back where he found it (p. 97/142). - When the small group from Qatar is doing their second "stoning of Satan", they realize (even the brother whom 'Fitna' once compared to the ultra-conservative Saudi scholar Ibn Bāz - p. 12/11) that they forgot to gather pebbles. A man from Saudi Arabia offers them some, and when young people nearby hear that they are from Qatar, without doubt the richest oil producing country in the region, everybody wants to collect pebbles for them (pp. 136-137/132-133). 
life, the restrictions on agency, the lack of self-determination and freedom as an imprisonment (p. 11-12/10).

The overall image both texts convey by describing the stages of the Hajj is that of constant rush and hurry, waiting, congestion and holdups, fear of getting lost and claustrophobia, tensions and violence among the pilgrims and between them and the security staff. Whereas 'Fitna' once compares the Hajj with "going to war, including exhaustion and death" (p. 54/52), Al-e Ahmad says about the tawaf and $s a^{\prime} y$ : "Every time the good people return from circumambulation and $s a^{\prime} y$ it is as if they have just returned from the battle of Khaybar [battle fought in 628 at an oasis located in the north of Medina] - some part of them is injured" (p. 70/103). Repeatedly, he dismisses the hajj rituals as "mechanized primitivity/barbarism (badaviyyat-e motorizeh)" (p. 78/114; 88/129; 91/134). He finds the sa ' $y$ between Safa and Marwa, the ritual run performed by the pilgrims between the two hills about four hundred yards apart, now enclosed within the Grand Mosque, stupefying and disturbing: "The pressure of the crowd drives you on. [...] One is utterly helpless in the midst of such a multitude" (p. 62/91). In contrast to the walking around the Ka 'ba, which is in one direction without meeting a counter-flow, in the $s a^{\prime} y$, he goes on to say, you are "going and coming", and "what's really disturbing is the continual eye contact [...] two eyes without a "self"' (p. 62/91). He admits that he "was never able to do more than two laps" (p. 69/101, cf. 102/150-151). As latecomers, 'Fitna' and her mother experience the initial tawaf and sa ' $y$ in a rather calm atmosphere. But 'Fitna' is shocked by the behavior of the guide her brother had hired to assist them in performing the ritual. When he constantly pushes away other pilgrims and even kicks one of them praying near the Ka ba, she shouts at him and secretly refers to him as a monster. In the end, he refuses to accompany the two women on the $s a$ ' $y$ leaving it to a friend to do it instead, although he took a lot of money from her brother. Though this man was friendlier than his companion, the repeating of his prayers and formulas, "parroting without rhyme or reason", does not make sense to 'Fitna' (p. 43/41).

Both protagonists report blocked roads and a lot of jostling in the dense crowd in Mina. In Al-e Ahmad's words: "I was terrified for a moment by the pressure of the crowd. Alone in an unfamiliar crowd, everybody speaking another language. [...] In one place where the road was blocked, the crush of the crowd was so concentrated that you were terrified" (p. 86, 87/125, 127). And 'Fitna' feels frightened by the waves of pilgrims dressed in white (p. 83/81; 125/121). The ceremony of 'stoning the Jamrahs' (pillars symbolizing "Satan") induces her to reflect on the devil: "Is there a devil? [...] Is it not possible that the devil is the victim of our wishes? Can't it be that we ourselves are the Evil Ones?" (p. 81/78). And during the second stoning of the pillars, she asks herself, "Does Satan really stand here? Does he feel our stones? How can I be sure about that? If I asked a Shaykh, he would accuse me of unbelief. [...] Is it not our right to ask and our right to get answers?" (p. 137/133). Witnessing the slaughtering of thousands of sheep and goats for the 'Id al-Adha is depicted by Al-e Ahmad as a traumatic experience ("the most terrifying facet of this motorized primitivity" - p. 88/129). He is disgusted by the cruelty and wastefulness of the sacrificial slaughter (seeing the slaughter- 
house once, "is the best possible advertisement for vegetarianism" - p. 88/129), offers psychoanalytical explanations for it, roughly estimates the amount of meat wasted $^{21}$ in these sacrifices, and provides the reader with proposals for what can be done with that meat (send them "as gifts to the poor of the world" - p. 89/130).

After the exertions of the past days, the farewell tawaf seems to be an easy task for the protagonists, despite the busy throng around the Ka'ba - maybe in joyful anticipation of going home? 'Fitna' emphasizes that "everything went perfectly after the second stoning ceremony" (p. 157/151). Al-e Ahmad, who in contrast to 'Fitna' only once mentioned that he felt homesick (p. 54/80), admits that he is "gradually losing the inclination and the energy to write notes" because " $[\mathrm{T}]$ he novelty of the trip has worn off" (p. 111/164: Täzegi-ye safar gozāshteh ast), and writes on this final Hajj ritual, again in a form which other pilgrims would take as irreverence or even blasphemy: “Visit?' No. Goodbye. 'Goodbye'? And to God? Or to his house? When you don't put words in the right place, this is the way it goes" (p. 113/167).

Additional, recommended rituals at the Hajj, for instance drinking water from the well of Zamzam, are also mentioned in both texts. ${ }^{22}$ Whereas Al-e Ahmad still had the chance to inspect the well and witness the pipes connected to it, in 'Fitna's' times one could get the water only from taps. When she sees only modern taps, and not a spring as she expected, she refuses to drink the water, saying: "How I shall know that there is really Zamzam water coming out of the tap?" (p. 148/143) This is of course a legitimate question, as Shawkat M. Toorawa reports that when he visited the well in 1994, the water was mixed with plain water. ${ }^{23}$

Both narratives contain a number of complaints about minor or major flaws and shortcomings observed during the pilgrimage. Both narrators mention quarrels among the fellow pilgrims, speak about ignorant Shaykhs (or preachers), and report on rude, disgraceful, sometimes violent behavior of pilgrims, security staff members, and guides - not at all appropriate during this special sort of journey. It comes as no surprise that Al-e Ahmad is more outspoken in his critique of the Saudi authorities, their inefficiency, greed, and other shortcomings ${ }^{24}$ : from

21 Cf. remarks in D.E. Long, op. cit., p. 21.

22 For another additional, not even highly recommended visit when in Mecca, see Al-e Ahmad's report on his excursion to Mount Hira, or Jabal al-Nur, where the Prophet Muhammad is said to have received his first revelation. He comments: "You would think they could restore this place [...]. The foremost place of inspiration... the Prophet's place of refuge... and now it's in this condition!" (p. 109/161) Though 'Fitna' did not visit the place, she notes that she once saw it in TV "in a shameful condition” (p. 51/49).

23 This was in contrast to his visit in 1972, when a tap was visibly piped into the well. In 1994, the well was behind glass and the water was pumped to taps located on the outside walls of the Grand Mosque (Sh.M. Toorawa, Performing the Pilgrimage [in:] The Hajj: Pilgrimage in Islam, eds. E. Tagliacozzo, Sh.M. Toorawa, New York 2016, p. 227).

24 As M.C. Hillmann (op. cit., p. xxxi) remarks, this criticism can be read as "another manifestation of his nationalistic, anti-Arab sentiment", but as an "indirect criticism of the Pahlavi regime as well". There has been a lot of discussion of Al-e Ahmad's "xenophobic view toward the Arabs" (ibid.), but one should also consider that stereotypical thinking and undue generalizations are widespread among other national groups taking part in the Hajj. The cross-cultural differences experienced by pilgrims during the Hajj still needs to be explored thoroughly. The study by K. Bustamam-Ahmad, Z. Rahmi (Cross- 
the very beginning, he complains about disorganization and incompetence, although conceding that "the task [...] is not a simple one" (p. 14/22) and predicting improvements in the near future. ${ }^{25}$ Nonetheless, he goes on to say, "They have left the matter of the Hajj to the most backward, primitive, untutored, and poverty-stricken layers of society" (p. 14/22). That is why he calls several times for "placing the shrine cities and their administration under international control" (p. 85/124; see also p. 28/42; 31/46; 32/47; 65/95) - a demand that meanwhile, albeit in a slightly different form, is a major topic among reformers. ${ }^{26}$ At the same time, he recognizes the potential power of Muslims assembled at Mecca ( $\mathrm{p}$. $73 / 108 ; 85 / 124)$, but only under the condition of widespread reforms. ${ }^{27}$ Likewise he laments the deliberate destruction of graves ${ }^{28}$ and old buildings by the Wahhabites/Saudi authorities, and the poor sanitary conditions ${ }^{29}$, especially in public places, shortcomings in the supply of electricity and other services. ${ }^{30}$

About 50 years later the situation has of course improved, as the Iranian author had predicted. But still, 'Fitna' finds some public washrooms appalling: "Is this Somalia or Saudi Arabia?" she asks, when they stop in a service area on the road from Medina to Mecca, to which her brother enquires, whether she had expected a five stars hotel (p. 38/36). Indeed, the Qatari family group is privileged when compared to the Iranian counterpart in 1964. Whereas the latter stayed in modest rented houses, the Qataris stay in hotels and most often take a taxi. On the reconstruction around the holy sites of Mecca, 'Fitna' only notes that Mecca appeared to her to be a modern city, just like Cairo or Damascus (p. 51/49). Re-

-Cultural Differences Experienced During Hajj: A Case Study of Acehnese Hajj, "Studia Islamika: Indonesian Journal for Islamic Studies" 2018, vol. 25, no. 1, pp. 67-96) on pilgrims from Aceh shows similar perceptions of Arab and other foreign cultures among pilgrims coming together at the Hajj.

${ }_{25}$ Cf. J. Al-e Ahmad's remarks on Mina (p. 97/143): "it is evident that year after year the facilities, electricity, and water are improving".

26 According to R.R. Bianchi (The Hajj by Air [in:] The Hajj: Pilgrimage in Islam, eds. E. Tagliacozzo, Sh.M. Toorawa, New York 2016, p. 250), "the flaws of the current Hajj regime are an open secret in the Islamic world. Greater internationalization of decision making is at the top of nearly every reformer's list, Saudi Arabian hegemony over the Hajj and the holy cities is under constant assault".

27 "I'm saying that every year a million people take part in these rites, and if there were order, facilities, procedures, and creativity there could be a great power" (p. 85/124). Whereas in 1964 there were about one million Hajjis, at the beginning of the $21^{\text {st }}$ century the number has doubled.

28 Cf. S. Al-Sarhan, The Saudis as Managers of the Hajj [in:] The Hajj: Pilgrimage in Islam, ed. E. Tagliacozzo, Sh.M. Toorawa, New York 2016, pp. 205-206. (A number of Islamic shrines and tombs in Mecca had already been destroyed before the Saudis took over in Mecca. In Medina, the Saudis are said to have hired the Nakhawila, the Twelver Shiite minority in Medina, to demolish the graves). Since the destructions, the graves are unmarked, that is why Al-e Ahmad could not find any trace of his late brother in the Baqi'-cemetery (cf. p. 28/41). Al-e Ahmad had also contact to Nakhawila during his stay in Medina.

29 However, for instance in Mina, he also remarks that the pilgrims themselves are not concerned about cleanliness (J. Al-e Ahmad, p. 95/139). - At the same location, 'Fitna' cannot stand the smell in the public washroom although the other pilgrims seem not to be disgusted, as she is (A. Al-Qahtani, p. 55/53).

${ }^{30}$ In a few passages, he also speaks about the beauty of some landscapes (mountains, desert, crystal clear water - pp. 101-102/149-150; 119/175) and buildings (a charming mosque, a nice old wooden house - p. 106/157), wonderful smells ("Bedouin" coffee - p. 84/123) and tasty dishes (p. 17/26). 
lating to the commercialization of the Hajj, for Al-e Ahmad another stumbling block ("Pilgrimage and business are twins" - p. 114/168), she only feels disturbed when she notices that even at Mount Uhud merchants are selling their goods. ${ }^{31}$ Despite his many bitter comments on Saudi politics, Al-e Ahmad is equally critical of his fellow pilgrims, those among the Iranian group and other nationalities alike ${ }^{32}$, and sometimes does not see a great difference between the situation in Saudi Arabia and Iran. ${ }^{33}$ Gradually he gets annoyed especially by the "fanatics" in his group, their additional prayers and rowzehs (p. 79/116; 107/158). ${ }^{34}$ At the airport gate, when watching passengers for their aircraft complaining and quarreling with one another behind the closed gate for nearly an hour (p. 121/179), he concludes: "People have reverted to their true colors, showing themselves as they really are. Selfish and petty, intolerant of one another, deserving of whatever they have" (122/180). 'Fitna's' attacks on the establishment are directed in particular against traditional, conservative Shaykhs and their hypocrisy and double standard (p. 24/22; 97/95; 103-104/99-100).

\section{Effects of the Hajj for the Protagonists}

One can hardly discover any sign of devotion, commitment, and dedication towards the Hajj in either texts. The Hajj is portrayed as like any other journey, a necessary additional experience, an episode in life, but without perceptible spiritual benefits. For neither protagonist is it the starting point of transformation, not to speak of rebirth.

In summing up his journey, Al-e Ahmad writes:

Although it was quite ordinary, it was the basis of a kind of awakening, and if not an awakening - at least a skepticism. In this way I am smashing the steps of the world of certainty one by one with the pressure of experience, beneath my feet. And what is the result of a lifetime? That you come to doubt the truth, solidity, and reality of the primary axioms that bring certainty, give cause for reflection" (p. 123/181-182).

Hence, what remains, is a "religion of doubts" 35 , and the conviction that there is no absolute truth, just a continuing process of questioning and self-inquiry - the

31 Cf. a similar passage in Al-e Ahmad's account where he notes "the amazing way they carry on business in the vicinity of the Prophet's Mosque" (p. 20/31). However, he also mentions that the pilgrims themselves are engaged in small business in order to improve their financial situation (in this case his brother-in-law Javad who sells carpets - p. 41/61).

32 It is conspicuous that in the case of a group of Lebanese youths who play cards and listen to music on the radio in public, in a tent at Mina, he only remarks that they did it "without shame whatsoever" (p. 94/138). He does not moralize or admonish them. And in contrast to the violence of other pilgrims or the obscurantism of some Mullahs and Shaykhs, he does not even put an exclamation mark or offer any comment to the reader.

33 Cf. his remarks on a school and donkey drivers near Uhud (p. 37, 38/54, 56).

34 Rowzehs are verse accounts of the tragedy of Karbala in 680, the martyrdom of the third Shiite Imam Husayn.

35 Cf. A.S. Chaudhary, p. 29, 250 and passim. 
fate of every true intellectual - which only results in solutions for the time being, not an enduring solution of the essential dilemma. ${ }^{36}$

'Fitna' also has a sobering revelation during the Hajj when at the end of the journey she seems to have realized that she herself is (partly) to blame for her problems ("I have built this prison and locked the door ..." - p. 188-189/179180), not only her family and the society. However, after her return from the Hajj, she again directly escapes to her room ("my paradise" - p. 181/173). In the aircraft on her flight back she calms down - but due to the fact that her mother has survived the Hajj and she is finally going home.

On the whole, one can find only brief moments of personal religious emotions in both narratives. But, whenever such moments are there or approaching, they are suddenly interrupted by basic realities or needs. It is noteworthy that the only scenes which come close to the narrator having a kind of 'religious' experience occur while praying in the Prophet's Mosque in Medina. Al-e Ahmad reports how he started crying and abruptly fled the Mosque when he saw how the people circumambulating the Prophet's grave "were climbing all over one another to kiss the shrine" (p. 22/33). 'Fitna' felt a moment of reverence, love, or weakness in the Prophet's Mosque (p. 25/23). When she approached the "House of God", she expected she would cry like at the Prophet's grave; however, nothing like this happened: she went to the Ka'ba as if she already knew it (p. 41/39).

In all, for both protagonists the Hajj is primarily an inner journey toward an understanding of oneself, not a voyage toward God. ${ }^{37} \mathrm{Al}-\mathrm{e}$ Ahmad makes this very clear: finally, he did go on Hajj to see, to witness, etc., but not in search of God. And he adds, "God is everywhere for those who believe in him" (p. 124/183). Moreover, he most often invokes God when he wishes to be safe from annoying people (porters, beggars, police). 'Fitna' uses the honorific phrase (PBUH, Peace Be Upon Him) whenever mentioning the Prophet Muhammad - apparently out of an internalized convention. Neither of them inserts quotes from the Quran or Hadith, as conventional Hajj travelogues do.

In the end, both are more interested in exploring the self than in expressing traditional religious pieties. In the same vein, they seem to advocate a moderate, pluralist, reasonable, and tolerant Islam, not divided by sectarian differences. The "fanatic" Shaykh in the Iranian group wonders that Al-e Ahmad prays with the Sunnites instead of praying behind him (p. 55/82). 'Fitna' admits that she never met a Shiite in person but when she hears, that Shiites deliberately disturb Sunnites at the Prophet's grave, she asks herself: "Do we think so negatively of Shiites, because they have another confession than we have? [...] Aren't we those who provoke them with our attacks on their confession?" (p. 26-27/24-25).

36 This also seems to be out of reach. As Al-e Ahmad points out: "In our system, neither the individual nor society has priority. Priority goes to the world of the unseen, which is connected to the bazaar, and has come under the control of companies. The individual and society [...] are two sides of the same coin" (p. 63/93-94).

37 Cf. E. Tagliacozzo, Sh. M. Toorawa, Introduction [in:] The Hajj: Pilgrimage in Islam, ed. E. Tagliacozzo, Sh. M. Toorawa, New York 2016, p. 9. 


\section{Concluding Remarks}

Michael C. Hillmann has pointed to the impact that the travel diary of Al-e Ahmad had on more recent safarnamehs in Persian, among them volumes by two of his former followers, and compared the influence of his travelogue with Naser-e Khosrow's. ${ }^{38}$ In his analysis of five recent accounts of the Hajj, Michael Wolfe has recognized a similarity between a scene described in Asra Nomani's Standing Alone in Mecca (2005) and Al-e Ahmad's diary. ${ }^{39}$ When I wrote my paper on the novel Fitna, I concentrated on the more or less admitted or indicated influences and intertextual references to Arabic (especially Gulf) and international literature. However, now, after reading both narratives again thoroughly, I am convinced that the parallels and similarities referred to above are obvious. ${ }^{40}$ Thus, I suggest that with his Lost in the Crowd, Al-e Ahmad has established a discursive pattern for other religious doubters among Muslims, Shiites and Sunnites alike. It goes without saying that this assumption needs further evidence, but such an effort may be the subject of future research.

\section{Bibliography}

Āl-e Ahmad J., Lost in the Crowd, transl. J. Green, Washington, D.C. 1985.

$\bar{A}$ l-e Aḥmad J., Khasī dar mīqāt: Safar-nāme, $4^{\text {th }}$ ed., Tehran 1375/1996.

Al-Qahtani A., Fitna: Roman, transl. C. Battermann, Cologne 2011.

Al-Qaḥțānī A., Fitna, $2^{\text {nd }}$ ed., Beirut 2007.

Al-Sarhan S., The Saudis as Managers of the Hajj [in:] The Hajj: Pilgrimage in Islam, eds. E. Tagliacozzo, Sh.M. Toorawa, New York 2016.

Axworthy M., The Revolution that Shook the World, "New Statesman" 2019, 15 February, vol. 148, issue 5458 .

38 M.C. Hillmann, op. cit., p. xxx.

39 M. Wolfe, The Pilgrim's Complaint: Recent Accounts of the Hajj [in:] The Hajj: Pilgrimage in Islam, eds. E. Tagliacozzo, Sh.M. Toorawa, New York 2016, p. 266.

40 There are also interesting similarities with the results of the empirical studies relating to nonbelievers on the Camino mentioned above. One may also recognize parallels to post-secular pilgrimages (cf. R. Illman Embracing Complexity: The Post-secular Pilgrimage of Eric-Emmanual Schmitt, "Scripta Instituti Donneriani Aboensis" 2010, vol. 10, pp. 228-243; P.J. Margry, Secular Pilgrimage: A Contradiction in Terms [in:] Shrines and Pilgrimage in the Modern World: New Itineraries into the Sacred, ed. P.J. Margry, Amsterdam 2008, pp. 13-46). The differences in the narratives analyzed above are mainly due to the gender perspective and to the time, context, style and genre. Al-e Ahmad is mostly distracted by observing beautiful women passing by, but he also acknowledges, for example, that "the women are really just spectators in these rites" (p. 65/96), and those who attempt to transgress the norms, are usually ordered to take the place patriarchal norms prescribe for them. To some extent, the self-portrayal of 'Fitna' comes close to his description of a gharbzadeh, a person incapable of commitment: "a man totally without belief or convictions [...] not only believes in nothing, but also does not actively disbelieve in anything... He cares neither whether society is transformed or not, nor whether religion or irreligion prevails [...]. He is indifferent." (Al-e Ahmad, Occidentosis Gharbzadegi, as quoted by A. S. Chaudhary, op. cit., p. 132). Chaudhary (ibid., p. 133) adds: "In the place of performance qua identity, the gharbzadeh has pure performance, performance qua performance". 
Badry R., Trapped in Between Two Worlds: The Novel "Fitna" (2007) by Amira AlQahtani [in:], Proceedings of the $3^{\text {rd }}$ International Conference on the History of Arabic Literature, ed. O. Khomitska, Kiev 2020, (forthcoming).

Bianchi R.R., The Hajj by Air [in:] The Hajj: Pilgrimage in Islam, eds. E. Tagliacozzo, Sh.M. Toorawa, New York 2016.

Blackwell R., Motivation for Pilgrimage: Using Theory to Explore Motivations, "Scripta Instituti Donneriani Aboensis" 2010, vol. 10.

Bustamam-Ahmad K., Rahmi, Z., Cross-Cultural Differences Experienced During Hajj: A Case Study of Acehnese Hajj, "Studia Islamika: Indonesian Journal for Islamic Studies" 2018, vol. 25, no. 1.

Chaudhary A.S., Religions of Doubt: Religion, Critique, and Modernity in Jalal Al-e Ahmad and Walter Benjamin, PhD-thesis, Columbia University 2013.

Clinton J. W., Āl-e Ahmad, Jalāl [in:] Encyclopaedia Iranica, ed. E. Yarshater, http:// www.iranicaonline.org/articles/al-e-ahmad-jalal-1302-48-s (access: 21.02.2020).

Coleman [III] T.J., Hood [Jr.] R.W., Streib H., An Introduction to Atheism, Agnosticism, and Non-Religious Worldviews, "Psychology of Religion and Spirituality" 2018, vol. 10, no. 3 .

Dabashi H., Theology of Discontent: The Ideological Foundations of the Islamic Revolution in Iran, New York 1993.

Eslami K., Farhād Mīrzā Mo'tamad-Al-Dawla [in:] Encyclopaedia Iranica, ed. E. Yarshater, http://www.iranicaonline.org/articles/farhad-mirza-motamad-aldawla (access: 21.02.2020).

Farias M. et al., Atheists on the Santiago Way: Examining Motivations to go on Pilgrimage, "Sociology of Religion: Quarterly Review" 2019, vol. 80, no. 1.

Green J., Translator's Glossary and Bibliography [in:] J. Āl-e Ahmad, Lost in the Crowd, transl. J. Green, Washington, D.C. 1985.

Hillmann M.C., Introduction: Cultural Dilemmas of an Iranian Intellectual [in:] J. Āl-e Ahmad, Lost in the Crowd, transl. J. Green, Washington, D.C. 1985.

Hunsberger A.C., Nasir Khusraw, the Ruby of Badakhshan: A Portrait of the Persian Poet, Traveller and Philosopher, London-New York 2000.

Illman R., Embracing Complexity: The Post-secular Pilgrimage of Eric-Emmanual Schmitt, "Scripta Instituti Donneriani Aboensis" 2010, vol. 10.

Jahanpour F., (Review) "Lost in the Crowd". By Jalal Al-e Ahmad. Translated by John Green with Ahmad Alizadeh and Farzin Yazdanfar. Washington, D.C.: Three Continents Press, 1985, "Iranian Studies" 1985, vol. 18, no. 2/4.

Jeffrey J., The Making of a Modern Pilgrim: The Camino de Santiago, "The Humanist" 2018, Jan.-Febp.

Knysh A., Islamic Mysticism: A Short History, Leiden 2010.

Kotiah S., A la Brasileña: Pilgrimage in Paulo Coelho's Writings, "Asian Journal of Latin American Studies" 2016, vol. 29, no. 2.

Long D.E., The Hajj Today: A Survey of the Contemporary Makkah Pilgrimage, Washington, D.C. 1979.

Margry P.J., Secular Pilgrimage: A Contradiction in Terms [in:] Shrines and Pilgrimage in the Modern World: New Itineraries into the Sacred, ed. P.J. Margry, Amsterdam 2008.

Nanji A., Nāșir-i Khusraw [in:] The Encyclopaedia of Islam, second edition, ed. P. Bearman, https://referenceworks.brillonline.com/entries/encyclopaedia-of- 
islam-2/nasir-i-khusraw-SIM_5827?s.num=215\&s.rows=100\&s.start=160 （access: 21.02 .2020$)$.

Nikpour G., Revolutionary Journeys, Revolutionary Practice: The Hajj Writings of Jalal Al-e Ahmad and Malcom X, "Comparative Studies of South Asia, Africa and the Middle East" 2014, vol. 34, no. 1.

Pedersen C.V., Āl-i Ahmad, Jalāl [in:] Encyclopaedia of Islam, THREE, ed. K. Fleet et al., https://referenceworks.brillonline.com/entries/encyclopaedia-of-islam-3/ali-ahmad-jalal-COM_24840?s.num=0\&s.rows=100\&s.f.s2_parent=s.f.book.encyclopaedia-of-islam-3\&s.q=Al-i+Ahmad (access: 21.02.2020).

Schnell T., Pali S., Pilgrimage Today: The Meaning-making Potential of Ritual, "Mental Health, Religion and Culture" 2013, vol. 16, no. 9.

Shiravand S., Sovereignty without Nationalism, Islam without God: A Critical Study of the Works of Jalal Al-e Ahmad, PhD-thesis, Dept. of Sociology, University of Alberta 2015.

Tagliacozzo E., Toorawa Sh. M., Introduction [in:] The Hajj: Pilgrimage in Islam, eds. E. Tagliacozzo, Sh.M. Toorawa, New York 2016.

Toorawa Sh.M., Performing the Pilgrimage [in:] The Hajj: Pilgrimage in Islam, eds. E. Tagliacozzo, Sh.M. Toorawa, New York 2016.

Wolfe M., The Pilgrim's Complaint: Recent Accounts of the Hajj [in:] The Hajj: Pilgrimage in Islam, eds. E. Tagliacozzo, Sh.M. Toorawa, New York 2016. 